\title{
EFFECT OF DIGOXIN ON THE CIRCULATION IN NORMAL MAN
}

BY

\begin{abstract}
ARTHUR SELZER, HERBERT N. HULTGREN, CARL L. EBNOTHER, HERBERT W. BRADLEY, AND ARTHUR O. STONE
\end{abstract}

From the Medical Service, Veterans Administration Hospital, and the Department of Medicine, Stanford University School of Medicine, San Francisco, California, U.S.A.

Received November 13, 1958

Digitalis is one of the oldest and most widely used drugs in clinical medicine. Its action in congestive cardiac failure has been thoroughly studied by many workers. Its action upon the normal circulation, however, has received relatively little attention. The concept that it lowers cardiac output and reduces central venous pressure in normal subjects continues to be expressed by many workers. This view, based on studies employing older, often inadequate methods, has been neither confirmed nor disproved by means of existing hæmodynamic techniques. This study, utilizing the technique of cardiac catheterization, was undertaken for the purpose of investigating the hæmodynamic effect of digoxin upon the circulation in 12 normal subjects.

\section{MATERIALS AND MeTHODS}

All twelve patients were carefully investigated by clinical, electrocardiographic, and radiological methods, and in none was there any evidence of significant cardiovascular abnormality. Sedatives $(0 \cdot 1 \mathrm{~g}$. sodium pentobarbital) were administered to five patients prior to the study. Special care was exercised that all measurements should be performed during a suitable post-absorptive steady state: that this was achieved is indicated by the small variation in duplicate control measurements prior to the administration of digoxin. Cardiac catheterization was performed in the usual manner. A branch of the basilic vein was dissected free under local procaine anæsthesia and a large size (No. 9F) cardiac catheter was introduced and guided under fluoroscopic control into the right ventricle and pulmonary artery. Pressures were recorded using strain gauge transducers and a direct writing oscillograph (Sanborn). The tip of the catheter was then withdrawn to the centre of the right atrium. For the remainder of the study frequent or continuous records of right atrial pressure were obtained. The sensitivity of the system was adjusted so that a deflection of $1 \mathrm{~cm}$. on the tracing was equal to $1 \mathrm{~mm}$. $\mathrm{Hg}$ pressure change. The zero reference point was midway between the recumbent patient's spine and the sternum. The reference point was rechecked at frequent intervals during the study. With the catheter tip in the right atrium, and when the patient had reached a satisfactory steady state after 15 minutes resting period, two control determinations of the cardiac output were made with a 15 to 20 minute interval between them. Oxygen consumptions were obtained by analysis of duplicate samples for oxygen and carbon dioxide in the patient's expired air collected in a Tissot spirometer during a three-minute period. Midway during the air collection period simultaneous samples were withdrawn from the right atrium and brachial artery, the latter through an indwelling arterial needle. Duplicate analyses for oxygen and carbon dioxide were performed using Van Slyke and McNeill's method. Respiratory quotients were calculated for each determination. Intermittent or continuous records of an electrocardiogram and, in eight patients, brachial arterial pressure tracings were obtained. 
Following the control period digoxin, in a dose varying from 1.25 to $2.0 \mathrm{mg}$., was injected through the catheter over a five-minute period. Observations were made following the administration of the drug up to 45 and 90 minutes after the injection, the mean period being 54 minutes. Two further determinations of the cardiac output were made 15 to 20 minutes apart during the final half hour of the observation period. All determinations were made simultaneously. Heart rate, right atrial pressure, and arterial pressures were read from the record at the time of the determination of the cardiac output.

The question of the reliability of the method used in this study in detecting circulatory changes that may have been brought on by the administration of the drug was given careful consideration and necessitated some ancillary observations. The reproducibility of the determinations of cardiac output in our laboratory has been studied and reported earlier (Selzer and Sudrann, 1958); it was shown that the median error for two determinations of cardiac output was 8.6 per cent and for two determinations of the arteriovenous oxygen difference was 4.8 per cent. These findings are similar to those of Harvey et al. (1949) and Donald et al. (1953), the latter investigators finding a standard error of a single observation to be 8.1 per cent. It is probable therefore that a difference of 10 per cent or more between two successive determinations of cardiac output represents a change in output. Inasmuch as this study involved continuous measurement of central venous pressure, samples of mixed venous blood had to be obtained from the right atrium instead of the customary collection from the pulmonary artery. In order to determine whether the possibility of streamlining may have lessened the reliability of the mixed venous blood samples taken from that source, duplicate determinations were collected from the right atrium of 26 patients with normal or abnormal circulatory apparatus and their reproducibility tested in a manner similar to that of the 167 pairs of determinations taken from the pulmonary artery (Selzer and Sudrann, 1958).

Finally, it was thought necessary to organize a control study of central venous pressure regarding the possible effect of the recumbent position during routine cardiac catheterizations. In 36 unselected cardiac catheterizations, measurements of right atrial pressure were made at the beginning and the termination of the procedure. Patients who had elevated right atrial pressure and those on whom an exercise test was performed were excluded. The series consisted of 10 subjects without significant cardiovascular disorder and 22 patients with a variety of congenital or acquired cardiovascular conditions. The time interval between the initial and terminal determinations varied from 20 to 60 minutes, the average being 30 minutes, during which time the inactive patients were resting recumbent on the fluoroscopic table.

\section{RESULTS}

Of the 12 patients in the series, two developed a disturbance of cardiac rhythm during the study: one had a paroxysm of atrial fibrillation with a slow ventricular rate and one developed partial atrioventricular block with dropped beats. All patients had normal systolic blood pressures, normal right atrial pressures, and normal cardiac rates. Cardiac output was within the normal zone with the exception of case G.F., where it was $2.351 . / \mathrm{min} . / \mathrm{m} .{ }^{2}$. This patient's study was performed during a paroxysm of atrial fibrillation, and it is probable that the abnormally low cardiac output was related to the arrhythmia. Three patients showed outputs within the range of 2.5 to $2.81 . / \mathrm{min} . / \mathrm{m} .^{2}$ which is considered normal for subjects of advancing age (Brandfonbrenner et al., 1955). The data are summarized in Table $I$.

It is seen from the Table that no significant change has been demonstrated in the mean values of any of the hæmodynamic events studied. A statistical analysis of the data, shown in Table II, fails to show a significant trend. Yet, the mean arteriovenous oxygen difference and the cardiac output show a slight rise and fall respectively. It is obvious that the slight change is due to a significant increase in arteriovenous oxygen difference of 13 per cent (F.B.), 23 per cent (B.C.) and 12 per cent (R.N.) and due to a significant fall in cardiac output of 22 per cent (F B ) and 37 per cent (B C.). Right atrial pressure showed a slight, statistically not significant, fall that was caused by a fall of $2 \cdot 1 \mathrm{~mm}$. (H.B.) and $5 \mathrm{~mm}$. (L.W.). The cardiac rate decreased significantly in four 
TABLE I

Findings After Administration of Digoxin to Twelve Subjects without Demonstrable Cardiac DISEASE

\begin{tabular}{|c|c|c|c|c|c|c|c|c|c|c|}
\hline No. & $\begin{array}{l}\text { Age } \\
\text { yr. }\end{array}$ & Time & $\begin{array}{l}\mathrm{O}_{2} \text { cons. } \\
\mathrm{ml} . / \mathrm{min} .\end{array}$ & $\begin{array}{c}\text { AV diff. } \\
\text { ml./100 ml. }\end{array}$ & $\begin{array}{c}\text { Cardiac } \\
\text { output } \\
1 / \mathrm{min} . / \mathrm{m} .2\end{array}$ & $\begin{array}{l}\text { R.A.P. } \\
\text { mm. Hg }\end{array}$ & $\begin{array}{l}\text { Arterial } \\
\text { pressure } \\
\mathrm{mm} . \mathrm{Hg}\end{array}$ & $\begin{array}{c}\text { Heart } \\
\text { rate/min. }\end{array}$ & EC & $\begin{array}{c}\text { Digoxin } \\
\text { mg. }\end{array}$ \\
\hline \multirow[t]{2}{*}{ 1. H.B. .. } & \multirow[t]{2}{*}{63} & $\begin{array}{l}-20 \\
-5\end{array}$ & $\begin{array}{l}222 \\
234\end{array}$ & $\begin{array}{l}5.0 \\
5.0\end{array}$ & $\begin{array}{l}2.45 \\
2.59\end{array}$ & $\begin{array}{l}6 \cdot 5 \\
6 \cdot 0\end{array}$ & $\begin{array}{l}130 / 81 \\
134 / 90\end{array}$ & $\begin{array}{l}78 \\
78\end{array}$ & \multirow{2}{*}{+} & \multirow[t]{2}{*}{$1 \cdot 25$} \\
\hline & & $\begin{array}{l}+30 \\
+50\end{array}$ & $\begin{array}{l}224 \\
239\end{array}$ & $\begin{array}{l}4.9 \\
5 \cdot 5\end{array}$ & $\begin{array}{l}2 \cdot 53 \\
2 \cdot 40\end{array}$ & $\begin{array}{l}4 \cdot 3 \\
4 \cdot 0\end{array}$ & $\begin{array}{l}143 / 88 \\
129 / 90\end{array}$ & $\begin{array}{l}77 \\
80\end{array}$ & & \\
\hline \multirow[t]{2}{*}{ 2. C.L. .. } & \multirow[t]{2}{*}{33} & $\begin{array}{l}-20 \\
-5\end{array}$ & $\begin{array}{l}229 \\
235\end{array}$ & $\begin{array}{l}4 \cdot 5 \\
4 \cdot 3\end{array}$ & $\begin{array}{l}2 \cdot 76 \\
2 \cdot 98\end{array}$ & $\begin{array}{l}5 \cdot 0 \\
6 \cdot 0\end{array}$ & $\begin{array}{l}110 / 80 \\
118 / 90\end{array}$ & $\begin{array}{l}90 \\
86\end{array}$ & \multirow[t]{2}{*}{+} & \multirow[t]{2}{*}{$2 \cdot 0$} \\
\hline & & $\begin{array}{l}+15 \\
+30 \\
+45\end{array}$ & $\begin{array}{l}232 \\
242 \\
225\end{array}$ & $\begin{array}{l}5 \cdot 2 \\
4 \cdot 6 \\
4 \cdot 7\end{array}$ & $\begin{array}{l}2 \cdot 44 \\
2 \cdot 87 \\
2 \cdot 60\end{array}$ & $\begin{array}{l}4 \cdot 0 \\
4 \cdot 0 \\
5 \cdot 0\end{array}$ & $\begin{array}{c}108 / 78 \\
116 / 50 \\
-\end{array}$ & $\begin{array}{l}92 \\
92 \\
92\end{array}$ & & \\
\hline \multirow[t]{2}{*}{ 3. L.B. .. } & \multirow[t]{2}{*}{28} & $\begin{array}{l}-20 \\
-5\end{array}$ & $\begin{array}{l}308 \\
276\end{array}$ & $\begin{array}{l}5 \cdot 4 \\
5 \cdot 1\end{array}$ & $\begin{array}{l}2 \cdot 69 \\
2 \cdot 56\end{array}$ & $\begin{array}{l}3 \cdot 0 \\
4 \cdot 0\end{array}$ & 二 & $\begin{array}{l}70 \\
64\end{array}$ & \multirow[t]{2}{*}{ O } & \multirow[t]{2}{*}{$2 \cdot 0$} \\
\hline & & $\begin{array}{l}+20 \\
+40\end{array}$ & $\begin{array}{l}278 \\
284\end{array}$ & $\begin{array}{l}5 \cdot 3 \\
5 \cdot 8\end{array}$ & $\begin{array}{l}2 \cdot 48 \\
2 \cdot 21\end{array}$ & $\begin{array}{l}3.0 \\
3.0\end{array}$ & 二 & $\begin{array}{l}64 \\
64\end{array}$ & & \\
\hline \multirow[t]{2}{*}{ 4. R.J. .. } & \multirow[t]{2}{*}{52} & $\begin{array}{l}-20 \\
-5\end{array}$ & $\begin{array}{l}284 \\
291\end{array}$ & $\begin{array}{l}3.9 \\
4.9\end{array}$ & $\begin{array}{l}3.56 \\
2.94\end{array}$ & $\begin{array}{l}4 \cdot 0 \\
4 \cdot 0\end{array}$ & $\begin{array}{l}116 / 79 \\
115 / 69\end{array}$ & $\begin{array}{l}80 \\
80\end{array}$ & \multirow[t]{2}{*}{+} & \multirow[t]{2}{*}{$1 \cdot 5$} \\
\hline & & $\begin{array}{l}+25 \\
+45\end{array}$ & $\begin{array}{l}285 \\
243\end{array}$ & $\begin{array}{l}4 \cdot 4 \\
4 \cdot 0\end{array}$ & $\begin{array}{l}3.22 \\
3.03\end{array}$ & $\begin{array}{l}4 \cdot 0 \\
4 \cdot 0\end{array}$ & $\begin{array}{l}121 / 73 \\
129 / 73\end{array}$ & $\begin{array}{l}76 \\
74\end{array}$ & & \\
\hline \multirow[t]{2}{*}{ 5. F.B. .. } & \multirow[t]{2}{*}{59} & $\begin{array}{l}-20 \\
-5\end{array}$ & $\begin{array}{l}242 \\
210\end{array}$ & $\begin{array}{l}5 \cdot 7 \\
4 \cdot 5\end{array}$ & $\begin{array}{l}2.48 \\
2.73\end{array}$ & $\begin{array}{l}2 \cdot 7 \\
2 \cdot 7\end{array}$ & $\begin{array}{l}120 / 65 \\
125 / 65\end{array}$ & $\begin{array}{l}77 \\
83\end{array}$ & \multirow[t]{2}{*}{0} & \multirow[t]{2}{*}{$1 \cdot 25$} \\
\hline & & $\begin{array}{l}+30 \\
+50 \\
\end{array}$ & $\begin{array}{l}205 \\
211\end{array}$ & $\begin{array}{l}5 \cdot 8 \\
6.0\end{array}$ & $\begin{array}{l}2.05 \\
2.05\end{array}$ & $\begin{array}{l}3 \cdot 4 \\
3 \cdot 4\end{array}$ & $\begin{array}{l}124 / 70 \\
137 / 75\end{array}$ & $\begin{array}{l}79 \\
78\end{array}$ & & \\
\hline \multirow[t]{2}{*}{ 6. B.T. .. } & \multirow[t]{2}{*}{25} & $\begin{array}{l}-20 \\
-5 \\
\end{array}$ & $\begin{array}{l}253 \\
262\end{array}$ & $\begin{array}{l}3.9 \\
3.9\end{array}$ & $\begin{array}{l}3 \cdot 23 \\
3 \cdot 36 \\
\end{array}$ & $\begin{array}{l}4 \cdot 0 \\
4.5 \\
\end{array}$ & 二 & $\begin{array}{l}88 \\
88\end{array}$ & \multirow[t]{2}{*}{+} & \multirow[t]{2}{*}{2.0} \\
\hline & & $\begin{array}{l}+25 \\
+50 \\
\end{array}$ & $\begin{array}{l}257 \\
234 \\
\end{array}$ & $\begin{array}{l}3.9 \\
3.9 \\
\end{array}$ & $\begin{array}{l}3.28 \\
3.00 \\
\end{array}$ & $\begin{array}{l}4 \cdot 5 \\
4 \cdot 0 \\
\end{array}$ & 二 & $\begin{array}{l}68 \\
72 \\
\end{array}$ & & \\
\hline \multirow[t]{2}{*}{ 7. R.N... } & \multirow[t]{2}{*}{25} & $\begin{array}{l}-20 \\
-5 \\
\end{array}$ & $\begin{array}{l}249 \\
230 \\
\end{array}$ & $\begin{array}{l}3.8 \\
3.9 \\
\end{array}$ & $\begin{array}{l}3.41 \\
3.07 \\
\end{array}$ & $\begin{array}{l}4.0 \\
5.0 \\
\end{array}$ & $\begin{array}{l}125 / 82 \\
125 / 85\end{array}$ & $\begin{array}{l}90 \\
86\end{array}$ & \multirow[t]{2}{*}{+} & \multirow[t]{2}{*}{$2 \cdot 0$} \\
\hline & & $\begin{array}{l}+30 \\
+45\end{array}$ & $\begin{array}{l}228 \\
238\end{array}$ & $\begin{array}{l}3 \cdot 8 \\
4 \cdot 9\end{array}$ & $\begin{array}{l}3 \cdot 12 \\
2 \cdot 53\end{array}$ & $\begin{array}{l}4.0 \\
6.0\end{array}$ & $\begin{array}{l}135 / 87 \\
138 / 82\end{array}$ & $\begin{array}{l}82 \\
77\end{array}$ & & \\
\hline \multirow[t]{2}{*}{ 8. L.W... } & \multirow[t]{2}{*}{55} & $\begin{array}{l}-20 \\
-5\end{array}$ & $\begin{array}{l}182 \\
163\end{array}$ & $\begin{array}{l}4 \cdot 3 \\
4 \cdot 5\end{array}$ & $\begin{array}{l}2 \cdot 74 \\
2 \cdot 35\end{array}$ & $\begin{array}{l}8 \cdot 8 \\
5 \cdot 2\end{array}$ & $\begin{array}{l}111 / 69 \\
112 / 69\end{array}$ & $\begin{array}{l}87 \\
86\end{array}$ & \multirow[t]{2}{*}{0} & \multirow[t]{2}{*}{1.5} \\
\hline & & $\begin{array}{r}+30 \\
+50 \\
\end{array}$ & $\begin{array}{l}163 \\
169\end{array}$ & $\begin{array}{l}3.9 \\
4 \cdot 1\end{array}$ & $\begin{array}{l}2 \cdot 72 \\
2 \cdot 67\end{array}$ & $\begin{array}{l}2 \cdot 7 \\
2 \cdot 5\end{array}$ & $\begin{array}{l}134 / 76 \\
146 / 86\end{array}$ & $\begin{array}{l}82 \\
87\end{array}$ & & \\
\hline \multirow[t]{2}{*}{ 9. B.C. .. } & 62 & $\begin{array}{l}-20 \\
-5 \\
\end{array}$ & $\begin{array}{l}245 \\
239\end{array}$ & $\begin{array}{l}3 \cdot 5 \\
3 \cdot 5\end{array}$ & $\begin{array}{l}3 \cdot 70 \\
3 \cdot 61\end{array}$ & $\begin{array}{l}4.5 \\
3.5\end{array}$ & $\begin{array}{l}140 / 90 \\
140 / 95\end{array}$ & $\begin{array}{l}88 \\
89\end{array}$ & + & $1 \cdot 75$ \\
\hline & & $\begin{array}{l}+30 \\
+50\end{array}$ & $\begin{array}{l}209 \\
218\end{array}$ & $\begin{array}{l}5 \cdot 2 \\
4 \cdot 6\end{array}$ & $\begin{array}{l}2 \cdot 12 \\
2 \cdot 51\end{array}$ & $\begin{array}{l}3 \cdot 5 \\
3 \cdot 5\end{array}$ & $\begin{array}{l}158 / 105 \\
156 / 106\end{array}$ & $\begin{array}{l}94 \\
95\end{array}$ & & \\
\hline 10. R.H. & 20 & -5 & $\overline{200}$ & $\begin{array}{l}4.2 \\
3.9 \\
\end{array}$ & $3 \cdot 50$ & $\overline{4 \cdot 3}$ & 二 & $\overline{80}$ & $\mathbf{O}$ & $2 \cdot 0$ \\
\hline & & $\begin{array}{l}+30 \\
+55\end{array}$ & $\begin{array}{l}219 \\
234\end{array}$ & $\begin{array}{l}3.9 \\
4.0\end{array}$ & $\begin{array}{l}3.90 \\
4.00\end{array}$ & $\begin{array}{l}2 \cdot 5 \\
3 \cdot 0\end{array}$ & 二 & $\begin{array}{l}74 \\
65\end{array}$ & & \\
\hline
\end{tabular}


TABLE I-continued.

\begin{tabular}{|c|c|c|c|c|c|c|c|c|c|c|}
\hline No. & $\begin{array}{c}\text { Age } \\
\text { yr. }\end{array}$ & Time & $\begin{array}{l}\mathrm{O}_{2} \text { cons. } \\
\mathrm{ml} . / \mathrm{min} .\end{array}$ & $\begin{array}{c}\text { AV diff. } \\
\mathrm{ml} . / 100 \mathrm{ml}\end{array}$ & $\begin{array}{c}\text { Cardiac } \\
\text { output } \\
1 / \mathrm{min} . / \mathrm{m} .^{2}\end{array}$ & $\begin{array}{l}\text { R.A.P. } \\
\text { mm. Hg }\end{array}$ & $\begin{array}{l}\text { Arterial } \\
\text { pressure } \\
\text { mm. Hg. }\end{array}$ & $\begin{array}{c}\text { Heart } \\
\text { rate/min. }\end{array}$ & $\mathrm{EC}$ & $\begin{array}{l}\text { Digoxin } \\
\text { mg. }\end{array}$ \\
\hline \multirow[t]{2}{*}{ 11. E.S... } & \multirow[t]{2}{*}{21} & - & $\begin{array}{l}183 \\
228\end{array}$ & $\begin{array}{l}3 \cdot 2 \\
3 \cdot 7\end{array}$ & $\begin{array}{l}4 \cdot 05 \\
4 \cdot 32\end{array}$ & $\overline{5 \cdot 0}$ & $13 \overline{3 / 71}$ & $\begin{array}{l}70 \\
75\end{array}$ & \multirow[t]{2}{*}{+} & \multirow[t]{2}{*}{$1 \cdot 5$} \\
\hline & & $\begin{array}{l}+30 \\
+63 \\
+90\end{array}$ & $\begin{array}{l}221 \\
208 \\
219\end{array}$ & $\begin{array}{l}3 \cdot 9 \\
3 \cdot 7 \\
3 \cdot 5\end{array}$ & $\begin{array}{l}4 \cdot 00 \\
3 \cdot 95 \\
4 \cdot 10\end{array}$ & $\begin{array}{l}4 \cdot 0 \\
3 \cdot 0 \\
6 \cdot 0\end{array}$ & $\begin{array}{l}124 / 70 \\
111 / 50 \\
128 / 50\end{array}$ & $\begin{array}{l}65 \\
60 \\
55\end{array}$ & & \\
\hline \multirow[t]{2}{*}{ 12. G.F. } & \multirow[t]{2}{*}{27} & - & $\begin{array}{l}286 \\
312\end{array}$ & $\begin{array}{l}6 \cdot 3 \\
6 \cdot 4\end{array}$ & $\begin{array}{l}2 \cdot 25 \\
2 \cdot 45\end{array}$ & $\overline{3 \cdot 0}$ & - & $\overline{70}$ & \multirow[t]{2}{*}{+} & \multirow[t]{2}{*}{$2 \cdot 0$} \\
\hline & & $\begin{array}{l}+35 \\
+80\end{array}$ & $\begin{array}{l}316 \\
308\end{array}$ & $\begin{array}{l}6 \cdot 2 \\
5 \cdot 9\end{array}$ & $\begin{array}{l}2 \cdot 55 \\
2.60\end{array}$ & $\begin{array}{l}3 \cdot 0 \\
3 \cdot 0\end{array}$ & - & $\begin{array}{l}70 \\
70\end{array}$ & & \\
\hline \multirow[t]{2}{*}{ Mean } & \multirow[t]{2}{*}{-} & - & B: 241 & $4 \cdot 47$ & 3.03 & $4 \cdot 5$ & $124 / 81$ & $80 \cdot 7$ & \multirow[t]{2}{*}{-} & \multirow[t]{2}{*}{-} \\
\hline & & - & A: 235 & $4 \cdot 67$ & $2 \cdot 89$ & $3 \cdot 5$ & $131 / 77$ & $75 \cdot 6$ & & \\
\hline
\end{tabular}

Figures in column "time" indicate the number of minutes before $(-)$ and after $(+)$ the administration of digoxin. Figures in the bottom line represent mean values for all observations in each column, B, before, and A, after the administration of digoxin.

TABLE II

Confidence Intervals $(95 \%$ ) OF InCREASE* in Measurements Following Administration OF Digoxin IN NORMal INDIVIDUALS

\begin{tabular}{|c|c|c|c|}
\hline Variable & & Confidence intervals & Units \\
\hline $\begin{array}{l}\text { Arteriovenous oxygen } \\
\text { difference .. } \\
\text { Cardiac index } \\
\text { Stroke volume } \\
\text { Right atrial pressure } \\
\text { Heart rate } \\
\text { Systolic arterial pressure } \\
\text { Diastolic arterial pressure }\end{array}$ & $\begin{array}{l}\cdots \\
\cdots \\
\cdots \\
\cdots \\
\cdots \\
\cdots\end{array}$ & $\begin{array}{l}-0.11 \text { to }+0.52 \\
-0.246 \text { to }+0.092 \\
-7.47 \text { to }+9.47 \\
-1.72 \text { to }+0.21 \\
-8.47 \text { to }+0.31 \\
-1.20 \text { to }+16.5 \\
-5.26 \text { to }+7.76\end{array}$ & $\begin{array}{l}\text { vol. per } 100 \mathrm{ml} . \\
\text { l./min. } / \mathrm{m} .{ }^{2} \\
\text { ml./beat } \\
\mathrm{mm} . \mathrm{Hg} \\
\text { beats } / \mathrm{min} . \\
\mathrm{mm} . \mathrm{Hg} \\
\mathrm{mm} . \mathrm{Hg}\end{array}$ \\
\hline
\end{tabular}

* A decrease is represented by a negative number.

patients but the mean change for the group is not significant. The systemic arterial pressure increased $28 \mathrm{~mm}$. (systolic) in one patient. Diastolic pressures rose in two patients and fell in two.

It is noteworthy that the changes in the various hæmodynamic measurements that have been observed did not all occur in the same patients. The patient who exhibited the $5 \mathrm{~mm}$. fall in right atrial pressure was not one of the two who experienced a fall in cardiac output. This patient did, however, have the most significant pressor effect of the entire series. Except for this possible relationship, the appearance of the electrocardiographic changes, the mild pressor response, the effect upon the cardiac rate, the fall in cardiac output, and the decrease in central venous pressure were unrelated to each other.

Findings in the two control studies were as follows. A comparison of the reproducibility of duplicate determinations of right atrial blood in 26 cases with that in 167 cases in which samples were drawn from the pulmonary artery (Selzer and Sudrann, 1958) showed no significant difference, the median error of two determinations of right atrial blood being 1.7 per cent and of pulmonary arterial blood 1.9 per cent. The second control study dealing with the determination of right atrial pressure at the beginning and at the end of a cardiac catheterization study showed a trend in that the later reading showed lower values than the earlier one. This is presented in detail in Fig. 1, in which findings in the 10 normal subjects and in 26 cases with cardiac disease but not with right ventricular failure are presented: it shows that right atrial pressure fell 26 times, remained the same 6 times, and rose 3 times. 


\section{RIGHT ATRIAL PRESSURE ( 32 CASES)}

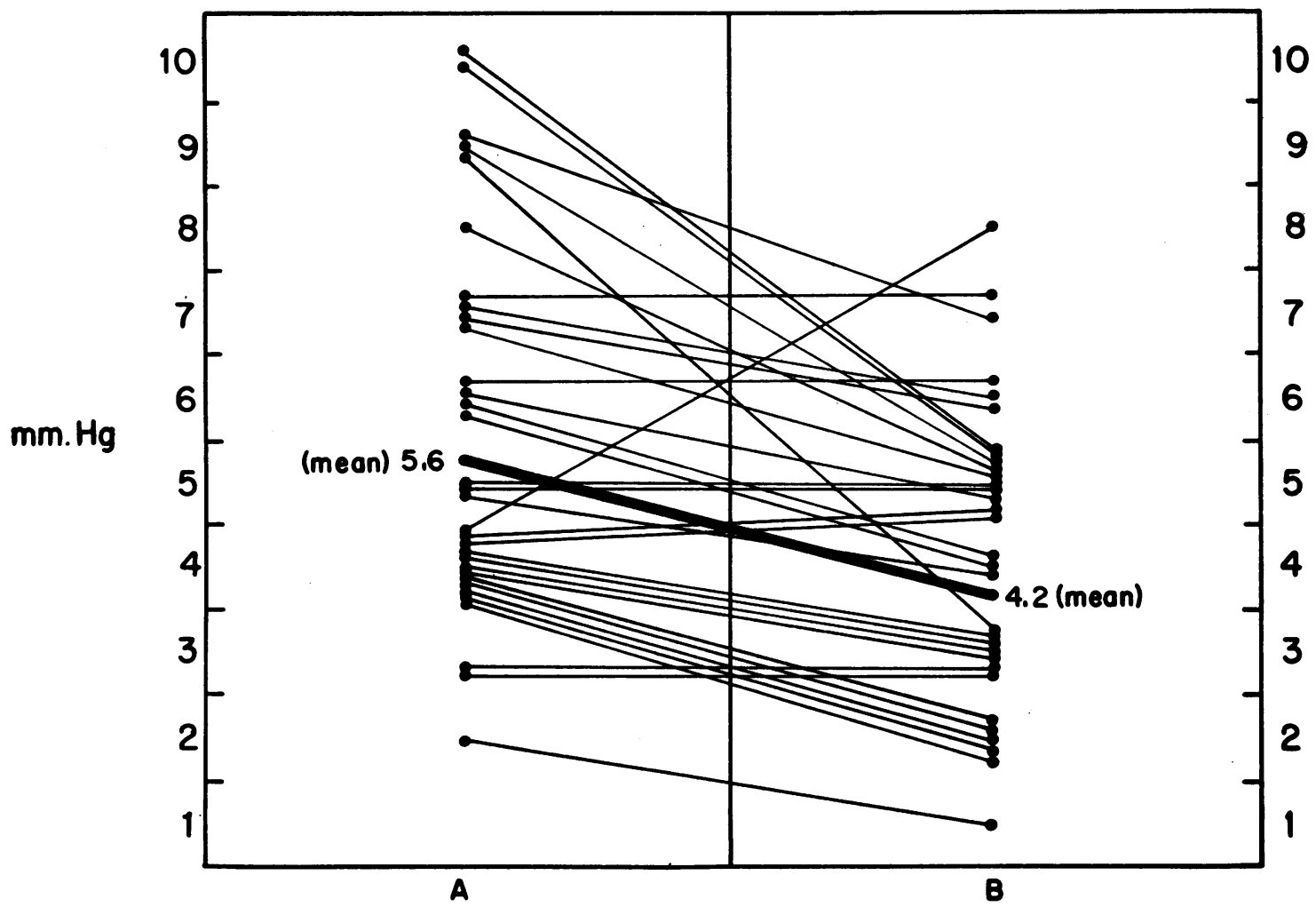

FIG. 1.-Graphic presentation of right atrial pressure at the beginning (A) and the end (B) of cardiac catheterization studies performed in 10 normal subjects and 22 patients with various forms of cardiac disease. Mean values are shown by the heavy line.

\section{Discussion}

The results of this study show no significant difference in any of the measurements before and after the administration of digoxin, as shown by the statistical analysis presented in Table II. However, before interpreting this finding as showing that digitalis has no demonstrable action upon the normal circulatory system, it is necessary to review the method carefully.

The dosage of the drug and the time of observation were comparable with those in other studies. The average amount of digoxin necessary to achieve single dose full digitalization in patients with cardiac failure is from 1.25 to $1.5 \mathrm{mg}$. (Goodman and Gilman, 1955). No patient in this study received less than $1.25 \mathrm{mg}$. and six received $2.0 \mathrm{mg}$. Eight of the 12 patients, including the two with transient arrhythmias, had electrocardiographic changes compatible with the digitalis effect, which suggested that an adequate dose of the drug was employed. It has been demonstrated that the effect of a single dose of digoxin given intravenously begins within 15 minutes and that hæmodynamic changes are evident within 30 to 45 minutes after administration. It seems likely that these observations made on patients with cardiac failure also apply to subjects without cardiac disease; normal subjects should not require larger doses or longer periods of observation than patients in cardiac failure.

The question as to whether measurements of cardiac output using the direct Fick method are 
sensitive enough to detect slight changes in cardiac output caused by digitalis should be answered in the affirmative. It has already been pointed out that a 10 per cent change in cardiac output is well outside the variability of the method. Furthermore, it is noteworthy that magnitude and consistency of changes in cardiac output caused by digitalis in cardiac failure are considerable, as shown by data collected from various investigators studying cardiac failure, wherein an increase in cardiac output of more than 20 per cent occurred in over 70 per cent of patients studied (Selzer $e t$ al., in press). If digitalis had a significant depressant effect upon the cardiac output in normal subjects, a significant trend or a considerable fall in the majority of cases or both should be apparent in a study of 12 cases. The significant fall in cardiac output that occurred in two patients cannot, therefore, be attributed to the action of the drug, as it is much more probable that these changes represented a spontaneous variation in cardiac output which may occur coincidentally with changes in steady state (Selzer and Sudrann, 1958).

The question of the reliability of right atrial samples as representing mixed venous blood admittedly has been approached only indirectly. However, an excellent reproducibility of duplicate samples as shown by the satisfactory closeness of the two determinations of the arterio-venous oxygen difference before and the two after the administration of the drug, further supported by close reproducibility of right atrial samples in 26 other patients, and by the fact that the mean arteriovenous oxygen difference for the series was normal ( 4.5 vol. per cent), implies strongly that right atrial samples are acceptable for the determination of cardiac output by the Fick formula.

As pointed out, two patients showed an appreciable decrease in right atrial pressure following the administration of digitalis. Similar observations have been made occasionally, though not consistently, by others studying the effect of digitalis upon the normal circulation (Dresdale et al., 1953) and by those studying the effect of digitalis on compensated heart disease (Harvey et al., 1949; Lagerlöf and Werkö, 1949). The demonstration in our control study, that there is a tendency for a fall in right atrial pressure in subjects recumbent for a long period of time, suggests strongly that all these findings in which the change suggested the action of the drug were probably caused by recumbency alone, and therefore represented an artefact.

On the basis of the above consideration it is believed that the methods and techniques used in this study were sufficiently accurate, and the series of cases sufficiently large to detect a hæmodynamic effect of digitalis upon the normal circulatory system, under basal resting conditions, if such an effect existed. The negative results of this study are further supported by three other series of observations: Ahmed et al. (1950) studied the action of ouabain in nine patients without cardiac disease and found no effect on right atrial pressure and no consistent effect on the cardiac output, which rose in three patients and fell in two. Harvey et al. (1949) found a fall in cardiac output in the two normal subjects studied, but no effect on right atrial pressure. Dresdale et al. (1953) found a fall in right atrial pressure in two of seven normal subjects and no consistent effect on the cardiac output. Thus a total of 31 subjects without evident cardiovascular disease had been studied regarding the hæmodynamic effects of digitalis with the use of cardiac catheterization technique and the direct Fick method of determination of cardiac output without showing any consistent effect that could be attributable to the action of the drug.

In view of these results, it is necessary now to review the studies that led to the acceptance of the widely held view that digitalis lowers the cardiac output and reduces venous pressure in normal man. Burwell et al. (1927) investigated the effects of the administration of 1.4 to $2 \cdot 7 \mathrm{~g}$. of digitalis in four normal subjects, performing daily determinations of cardiac output, using the $\mathrm{CO}_{2}$ method of Field. In five such studies performed in the four subjects, a mean fall in cardiac output of 16 per cent was observed although the decrease in four of the studies was less than this value. Stewart and Cohn (1932) employed the acetylene method of Grollman in seven studies on six patients: following the administration of digitalis, a mean decrease of 27 per cent in cardiac output occurred in six of the seven studies with a maximum effect 4 to 24 hours afterwards. Rytand (1933) gave digitalis to eight normal subjects and measured venous pressure in the arm vein prior to the administration and at intervals up to four days afterwards: a mean decline of 
$2 \mathrm{~cm}$. saline was noted from 24 to 36 hours after the administration, with a tendency to return to pre-digitalis levels on the third and fourth day.

Although the indirect equilibration techniques of Field and Grollman may have been fairly reliable methods of estimating cardiac output in normal subjects (Werkö et al., 1949; Chapman et al., 1950), the necessity of making repeated tests over a period of several days allowed many factors other than digitalis to influence the cardiac output. This was pointed out by Burwell (1927) who stated in commenting upon the results of his study "that the output of the heart remained, even after a lapse of weeks, somewhat below the pre-digitalis level, may be ascribed to greater co-operation and less effort on the part of the subject". An inspection of Rytand's (1938) data indicates that a slight fall in venous pressure occurred in five of nine studies. Here also it was necessary to make measurements over a period of two to four days to observe the peak effect of digitalis. Furthermore, subjects were studied in the supine position with the arm placed on the table at the same level as the back. It has been clearly demonstrated by Ryder et al. (1944) that in many normal subjects, especially when the arm is below the right atrium, collapse of the vein at the shoulder may occur. The pressure in the vein distal to this point then no longer reflects central venous pressure but local tissue pressure at the point of compression of the vein. The changes observed by Rytand (1933) therefore may not have reflected changes in central venous pressure, but may have been caused by alterations in segmental venous pressure, tissue pressure, or even postural changes.

In addition to fall in cardiac output and decrease in venous pressure, Stewart and Cohn (1932) also observed a decrease in cardiac size. The basis for this observation was a comparison of antero-posterior radiograms of normal subjects before and after the administration of digitalis. The estimation of cardiac size from one-dimensional roentgen films is notoriously inaccurate because of the indeterminable influence of the phase of cardiac cycle, the position of the diaphragm, and the effect of breath-holding upon the cardiac shadow.

Thus, the widely held views regarding the action of digitalis on the circulation of normal man are that digitalis $(a)$ lowers the cardiac output, $(b)$ reduces the cardiac size, and $(c)$ lowers venous pressure. The most widely accepted interpretation of these observations, that by Stewart and Cohn (1932) is that digitalis either reduces cardiac size by increasing the "diastolic" tone of the normal heart, thereby lowering the cardiac output, or that digitalis increases the strength of the cardiac contraction, reducing its size below the optimal efficiency with the resulting fall in cardiac output and decrease in venous pressure. An alternative interpretation, based on experimental studies of Dock and Tainter (1930) and accepted by Rytand (1933) suggests the fall in venous pressure caused by peripheral factors as the primary mechanism of the digitalis effect. It is noteworthy that most standard text-books and monographs dealing with various aspects of cardiac disease accept Stewart and Cohn's view regarding the digitalis effect on the normal circulation and consider digitalis as exerting an unfavourable effect on the heart in the absence of cardiac failure (Stewart, 1952; Friedberg, 1956; Fishberg, 1940).

It is seen that the foregoing views are based on observations regarding slow digitalization in not more than 10 subjects, using older methods, which are neither sensitive nor accurate enough to assure a relationship between the observed changes and the administration of the drug. On the other hand, a combined series of 31 normal subjects showed no consistent changes in cardiac output and in central venous pressure in response to acute digitalis administration, using methods capable of demonstrating changes in these two parameters, if such existed. One is therefore justified in concluding that digitalis has no demonstrable effect upon resting circulatory dynamics in normal subjects.

\section{SUMmaRY AND CONCLUSIONS}

$\mathrm{H}$ æmodynamic effects of digoxin have been investigated in 12 subjects in whom there was no clinical evidence of cardiac disease. The dose of digoxin varied from 1.25 to $2.0 \mathrm{mg}$. and the period of observation averaged one hour. More than half of the subjects showed the characteristic digitalis effect upon the electrocardiogram. 
Measurements of cardiac output, central venous pressure, arterial pressure, and cardiac rate, before and after the administration of the drug, showed no statistically significant difference.

The results of this study and of other observations employing current techniques suggest that digitalis exerts no significant hæmodynamic influence upon the circulation in the absence of cardiac disease or failure. The still widely accepted views of the "paradoxical" action of digitalis reducing cardiac output and exerting an unfavourable influence upon the normal circulatory system are examined critically and found no longer tenable.

\section{REFERENCES}

Ahmed, S., Bayliss, R. I. S., Briscoe, W. A., and McMichael, J. (1950). Clin. Sci., 9, 1.

Brandfonbrenner, M., Landown, M., and Shock, N. W. (1955). Circulation, 12, 557.

Burwell, C. S., Neighbors, de W., and Regen, E. W. (1927). J. clin. Invest., 5, 125.

Chapman, C., Taylor, H., Borden, C., Ebert, R., and Keys, A. (1950). J. clin. Invest., $29,651$.

Dock, W., and Tainter, M. L. (1930). J. clin. Invest., 8, 467.

Donald, K., Bishop, J., Cumming, G., and Wade, O. (1953). Clin. Sci., 12, 199.

Dresdale, D. T., Michtom, R. J., and Schultz, M. (1953). J. clin. Invest., $32,563$.

Fishberg, A. M. (1940). Heart Failure. 2nd ed., Lea \& Febiger, Philadelphia and London.

Friedberg, C. F. (1956). Diseases of the Heart. 2nd ed., W. B. Saunders Co., Philadelphia and London.

Goodman, L. S., and Gilman, A. (1955). The Pharmacological Basis of Therapeutics. 2nd ed., Macmillan Co., New York and London.

Harvey, R. M., Ferrer, M. I., Cathcart, R. T., Richards, D. W., and Cournand, A. (1949). Amer. J. Med., 7, 439.

Lagerlöf, H., and Werkö, L. (1949). Acta Cardiol., 4, 1.

Ryder, H., Molle, W., and Ferris, E. Jr. (1944). J. clin. Invest., 23, 333.

Rytand, D. A. (1933). J. clin. Invest., 12, 847.

Selzer, A., and Sudrann, R. (1958). Circulation Res., 6, 485.

-, Ebnother, C. L., Stone, A. O., and Bradley, H. W. In press.

Stewart, H. J., (1952). Cardiac Therapy. Hoeber, New York.

$\longrightarrow$, and Cohn, A. E. (1932). J. clin. Invest., 11, 917.

Werkö, L., Berseus, S., and Lagerlöf, H. (1949). J. clin. Invest., 28, 516. 